\title{
Genetic mechanisms affecting reconstitution of cell lines and immune reactions after hematopoietic stem cell transplantation
}

\author{
Kwiecinska K ${ }^{1,3}$, Bik-Multanowski $M^{2}$, Strojny $W^{1,3}$, Grabowska $A^{2}$, Korostynski $M^{4}$, Piechota $M^{4}$, Fijorek $K^{5}$, D Pietrys ${ }^{1}$, Balwierz $W^{1,3}$ and \\ Skoczen $\mathbf{S}^{1,3 *}$ \\ ${ }^{1}$ Department of Oncology and Hematology, University Children's Hospital, Jagiellonian University Medical College, 30-663 Krakow, Poland \\ ${ }^{2}$ Department of Medical Genetics, Institute of Pediatrics, Jagiellonian University Medical College, 30-663 Krakow, Poland \\ ${ }^{3}$ Department of Oncology and Hematology, Institute of Pediatrics, Jagiellonian University Medical College, 30-663 Krakow, Poland \\ ${ }^{4}$ Department of Molecular Neuropharmacology, Institute of Pharmacology of Polish Academy of Sciences, 30-663 Krakow, Poland \\ ${ }^{5}$ Department of Statistics, Cracow University of Economics, 30-663 Krakow, Poland
}

\begin{abstract}
Reconstitution of cell lines and occurrence of complications following hematopoietic stem cell transplantation (HSCT) are regulated by genome expression. Microarray technique allows for simultaneous assessment of expression of nearly all human genes. The objective of the study was to compare whole genome expression in children before and after HSCT.

A total of 44 children treated with HSCT were enrolled in the study. Gene expression was measured before HSCT (pre-HSCT group; $\mathrm{n}=44$ ) and after a median of 6 months after allogenic HSCT (post-HSCT group; $\mathrm{n}=27$; all children were included in the pre-HSCT group). Neoplasms were the indication for HSCT in $73 \%$ of the patients. Whole genome expression was assessed in leukocytes using GeneChip ${ }^{\circledR}$ HumanGene 1.0 ST microarray.

The GeneCards Human Genes Database was used for analysis of genes function. The analysis of genomic profiles before and after HSCT revealed 18 significantly different genes with defined function. These genes are responsible for proliferation and differentiation of cells (14 genes), apoptosis ( 8 genes), migration of cells ( 3 genes) and fluid/electrolyte homeostasis (2 genes).

Conclusions: Activation of genes involved in reconstitution of donor cell lines, and those related to immune reactions observed after HSCT, form the genetic background for physiological and pathological processes following HSCT.
\end{abstract}

\section{Introduction}

Allogeneic hematopoietic stem cell transplantation (HSCT) is currently a safe and life-saving treatment modality used in a wide spectrum of diseases [1-3].

However, transplant recipients are still at high risk of morbidity and mortality due to delay of reconstitution of cell lineages, prolonged treatment with multiple, nonspecific and toxic immunosuppressive drugs, and immune reactions like graft versus host disease (GvHD) or graft rejection (GR) [4-8]. All the observed processes are regulated by genetic machinery [9-11].

Two recent articles explain the role of gene analyses in the search for immunotherapy targets in malignant diseases and in the study of immune complications after HSCT. In the study by Pont MJ et al. microarray gene expression analysis on malignant and healthy hematopoietic cells and various non-hematopoietic cell types cultured under steady state and inflammatory conditions was performed. The goal of the research was to evaluate the value of the microarray dataset to analyze and select potential targets for immunotherapy of hematological malignancies. Gene expression profiles were generated for hematopoiesis-restricted minor histocompatibility antigens that are recognized by specific T cells in the context of HLA. The analysis confirmed restricted or predominant expression of these antigens in hematopoietic cells, but ARHGDIB and ITGB ${ }_{2}$ also showed intermediate and low expression in endothelial cells and fibroblasts, respectively. In addition to minor histocompatibility antigens, the authors generated gene expression profiles for surface antigens with known B-cell specific expression. Microarray analysis confirmed restricted or predominant expression of these antigens in (malignant) B cells. However, CD79B was also expressed in a variety of other (non-)hematopoietic cell types. For ROR1, microarray data confirmed overexpression in CLL as compared to healthy B cells. ROR1 expression was also found in biliary epithelialcells and to variable extents in skin fibroblasts. Those cell types originate from organs that are often targeted in detrimental immune responses after allogeneic stem cell transplantation leading to graft versus-host disease [12].

*Correspondence to: Szymon Skoczen, $\mathrm{MD}, \mathrm{PhD}$, Institute of Pediatrics, Jagiellonian University Medical College, 30-663 Krakow, Wielicka St. 265, 30 663 Krakow, Poland, E-mail: szymon.skoczen@uj.edu.pl

Key words: stem cell transplantation, immune reactions, microarrays, children

Received: February 01, 2019; Accepted: February 19, 2019; Published: February 22,2019 
In the second study by Inamoto $\mathrm{Y}$ et al. [13] candidate singlenucleotide polymorphisms (SNPs)were examined that have a welldocumented association with systemic sclerosis to determine whether these SNPs are also associated with the risk of sclerotic GvHD. The study cohort included 847 consecutive patients who were diagnosed with chronic GvHD. Genotyping was performed using microarrays, followed by imputation of unobserved SNPs. The donor rs10516487 TT genotype was associated with lower risk of sclerotic GvHD. Donor and recipient rs2056626 GG or GT genotypes and rs987870 CC genotypes were associated with higher risk of sclerotic GvHD. Additionally, the recipient $\mathrm{DPA} 1^{\star} 01: 03 \sim \mathrm{DPB} 1^{\star}$ 04:01 haplotype and certain amino acid substitutions in the recipient $\mathrm{P} 1$ peptide-binding pocket of the HLA DP heterodimer were associated with risk of sclerotic GvHD. Genetic components associated with systemic sclerosis are also associated with sclerotic GvHD. Authors concluded that HLA-DP-mediated antigen presentation, T-cell response, and B-cell activation have important roles in the pathogenic mechanisms of both diseases [13].

The aim of our study was to analyze the genome expression changes resulting from HSCT in pediatric population.

\section{Materials and methods}

This was a prospective study, the study group consisted of children and teenagers referred for HSCT, which was performed according to disease-specific treatment protocols. The study was approved by the Ethics Committee of the Jagiellonian University (KBET/96/B/2008). Written informed consent was obtained from all parents and from all patients $\geq 16$ years of age.

\section{Microarray analysis}

Blood samples $(1.5 \mathrm{~mL})$ were collected from each patient before conditioning and approximately six months after HSCT (median 6.3 months). Total RNA extraction from blood mononuclears was performed using RiboPure Blood Kit (Ambion, Life Technologies, Carlsbad, USA). Whole genome expression was assessed using GeneChip Human Gene 1.0 ST Arrays (Affymetrix, Santa Clara, USA). Whole transcript microarray experiment was performed according to the manufacturer's protocol (GeneChip Whole Transcript sense Target Labeling Assay Manual, Version 4).

\section{Statistical analysis}

The microarray data were preprocessed using the R/Bioconductor package [14-16]. Robust Multiarray Average (RMA) was used for normalization [17]. Quality control was performed by investigating Principal Component Analysis (PCA), Relative Log Expression (RLE) and Normalized Unscaled Standard Error (NUSE) plots.

Moderated t-tests [18] were used to detect the probes with different expression in various groups; the limma package [19] from the $\mathrm{R}$ software was used. It was assumed that the $\log 2$ transformed gene expression levels are normally distributed and the between-group variation is of comparable magnitude. Multiple testing correction (Benjamini-Hochberg procedure) was applied to control the false discovery rate (FDR) [20]. Significantly different expression in the probe sets was defined as multiple comparison-corrected two-sided $\mathrm{p}$-value $<0.05$. For comparison of gene expression levels (33000 genes studied) between the group of patients assessed before HSCT (preHSCT group) and the group of patients assessed after HSCT (postHSCT group) ANOVA filtering by p-value 0.00005 was used with expected false positive results equal to 2 .
The GeneCards Human Genes Database (www.genecards.org/) was used for analysis of genes function.

\section{Results}

\section{The study groups}

The pre-HSCT group included 44 patients ( 31 boys, 13 girls) aged 1.5 - 19 (median 10.5) years, referred to the Stem Cell Transplantation Centre of the University Children's Hospital in Krakow. Neoplasms were the indication for HSCT in $73 \%$ of children. The indications for HSCT are listed in Table 1 and types of HSCT procedures are listed in Table 2.

The post-HSCT group included 27 patients from the pre-HSCT group, aged $2.8-19.5$ (average 10.4) years. Six patients from the pre-HSCT group were excluded from the analysis due to technical reasons (poor quality of RNA sample) and another eleven patients were lost to follow up. Four children in the post-HSCT group died due to complications of treatment or disease progression, one child died because of GvHD. All patients in the post-HSCT group were treated with ablative conditioning regimens (Table 2). The key clinical characteristics of the patients are presented in Table 3.

\section{Whole genome expression}

All the primary microarray data were submitted to GEO public repository and are accessible using GEO Series accession

Table 1. Indications for HSCT (pre-HSCT group)

\begin{tabular}{|l|c|}
\hline Diagnosis & N ( \%) \\
\hline Acute lymphoblastic leukemia (ALL) & $17(38.6)$ \\
\hline Acute myeloblastic leukemia (AML) & $5(11.3)$ \\
\hline Acute bilineage leukemia (ABL) & $1(2.3)$ \\
\hline Chronic myelocytic leukemia (CML) & $1(2.3)$ \\
\hline Hodgkin Lymphoma (HD) & $2(4.6)$ \\
\hline Myelodysplastic syndrome (MDS) & $1(2.3)$ \\
\hline Juvenile myelomonocytic leukemia (JMML) and AML & $1(2.3)$ \\
\hline Neuroblastoma (NBL) & $4(9)$ \\
\hline Neoplastic diseases-total & $\mathbf{3 2}(\mathbf{7 3})$ \\
\hline Severe aplastic anemia (SAA) & $4(9)$ \\
\hline Blackfan-Diamond Anemia (BDA) & $1(2.3)$ \\
\hline Fanconi Anemia (FA) & $1(2.3)$ \\
\hline Chronic granulomatous disease (CGD) & $3(6.8)$ \\
\hline Autoimmune lymphoproliferative syndrome (ALPS) & $1(2.3)$ \\
\hline Hyper IgM syndrome (HIgM) & $1(2.3)$ \\
\hline Inherited neutropenia (IN) & $1(2.3)$ \\
\hline Non-neoplastic diseases-total & $\mathbf{1 2}(\mathbf{2 7})$ \\
\hline
\end{tabular}

Table 2. Types of HSCT procedures (ALL: Acute lymphoblastic leukemia; ALPS Autoimmune lymphoproliferative syndrome; AML: Acute myeloblastic leukemia; CGD: Chronic granulomatous disease; HIgM-hyper IgM syndrome; JMML: Juvenile myelomonocytic leukemia; MDS: Myelodysplastic syndrome; SAA: Severe aplastic anemia)

\begin{tabular}{|c|c|c|}
\hline Type of HSCT & n(\%) & Disease (n) \\
\hline \multirow{4}{*}{} & MUD-16(59) & ALL-9 \\
& & AML-4 \\
& & SAA-1 \\
\cline { 2 - 3 } & & CGD-2 \\
Allogeneic & & ALL-3 \\
$\mathrm{n}=27(100 \%)$ & SAA-2 \\
& MSD-9 (33) & JMML and AML-1 \\
& & CGD-1 \\
& & HIgM-1 \\
& & MDS-1 \\
\cline { 2 - 3 } & & SAA-1 \\
& & ALPS-1 \\
\hline
\end{tabular}


number GSE88852 (http://www.ncbi.nlm.nih.gov/geo/query/acc. cgi?acc $=$ GSE88852).

A summary of the differentially expressed genes and their function is presented in Table 4 and Figure 1.

A comparison of the pre-HSCT and post-HSCT groups revealed 26 genes having the highest expression differences ( $\mathrm{p}$-value 0.00005, expected false positive results equal to 2)-Figure 1. Based on search in the GeneCards - Human Genes Database (www.genecards.org/) well defined function was found in 18 cases. In the post-HSCT group gene activation (14 genes) was seen a little more frequently than gene inhibition (10 genes). Proliferation-related genes were activated (WBP1L, Lasp-1, CST7, EDARADD, ECOP, FAM53B, ST13) or suppressed (B3GALT2, TRMT5, PLAG1, DPPIV). Similarly, several apoptosis-related genes were activated (WBP1L, CSTN3, ZFP319, CST7, EDARADD) or suppressed (AREL1, ECOP, B3GALT2). Three genes were responsible for regulation of migration of cells, including lymphocytes T (IQSEC1, ST13, NR3C2). The function of T-cells was inhibited by DPPIV. Increased expression was observed for CST7. This gene is responsible for immune regulation through inhibition of a unique target in the hematopoietic system. Increased expression was also detected for genes ZFP319 and U2AF1 regulating differentiation and hematopoiesis respectively. On the other hand, inhibition of hematopoiesis was represented by TRMT5 and inhibition of erythropoiesis by DPPIV genes. Moreover, a decrease in expression of $S L C 4 A 10$ and $N R 3 C 2$ - genes regulating fluid and electrolyte homeostasis - was found.

\section{Discussion}

In our earlier study including 27 children treated with HSCT, we used pathway enrichment analysis of 250 overexpressed genes, and we identified five genomic pathways: "Allograft rejection", "Graft-versushost disease", "Type I diabetes mellitus", "Autoimmune thyroid disease" and "Viral myocarditis" [21]. In the present study we compared genome expression between the groups of children before HSCT and after allogeneic HSCT. Using conservative statistical criteria (p-value 0.00005
Table 3. Characteristics of the study groups (GvHD-graft-versus-host disease)

\begin{tabular}{|c|c|}
\hline \multicolumn{2}{|r|}{ Pre-HSCT group } \\
\hline $\mathrm{N}$ & 44 \\
\hline Sex & Boys 31 , Girls 13 \\
\hline Age (years) & $1.5-19$ (median 10.5$)$ \\
\hline $\begin{array}{l}\text { Chemotherapy before HSCT }(\%) \\
\text { First line } \\
\text { Second line } \\
\text { >third line }\end{array}$ & $\begin{array}{l}23(71 \%) \\
13 \\
9 \\
1\end{array}$ \\
\hline $\begin{array}{l}\text { Local radiotherapy } \\
\text { Cranial (dose) } \\
\text { Testes }\end{array}$ & $\begin{array}{l}7 \\
5(12 \mathrm{~Gy}-4,18 \mathrm{~Gy}-1) \\
2(12 \mathrm{~Gy} / 24 \mathrm{~Gy}, 18 \mathrm{~Gy} / 18 \mathrm{~Gy})\end{array}$ \\
\hline $\begin{array}{l}\text { Time since diagnosis and patient selection } \\
\text { (years) }\end{array}$ & Median, 1.4 ; range $0.08-12.9$ \\
\hline \multicolumn{2}{|l|}{ Post-HSCT group } \\
\hline $\mathrm{N}$ & 27 \\
\hline Sex & Boys 20, Girls 7 \\
\hline Age (years) & $2.8-19.5$ (median 9.9) \\
\hline $\begin{array}{l}\text { Conditioning regimen based on busulfan/ } \\
\text { treosulfan (n) }\end{array}$ & $16(59 \%)$ \\
\hline Total body irradiation-12Gy/6 fractions (n) & $7(26 \%)$ \\
\hline $\begin{array}{l}\text { GvHD prophylaxis (n) } \\
\text { Cyclosporin } \\
\text { Methotrexate+cyclosporin }\end{array}$ & $\begin{array}{l}4(15 \%) \\
23(85 \%)\end{array}$ \\
\hline GvHD (n) & $14(52 \%)$ \\
\hline $\begin{array}{l}\text { Median time from HSCT to the second } \\
\text { assessment (range) }\end{array}$ & 6.3 (5.9-19.1) months \\
\hline Systemic glucocorticoids (\%) & $25(93 \%)$ \\
\hline $\begin{array}{l}\text { Median and range of cumulative doses of } \\
\text { glucocorticoids (equivalent of prednisone) }\end{array}$ & $1531(29-9758) \mathrm{mg} / \mathrm{m}^{2}$ \\
\hline $\begin{array}{l}\text { Median duration of systemic glucocorticoid } \\
\text { therapy }\end{array}$ & $73(1-315)$ days \\
\hline $\begin{array}{l}\text { Median time since discontinuation of } \\
\text { glucocorticoids (range) }\end{array}$ & $3.5(0-14.3)$ months \\
\hline $\begin{array}{l}\text { Median time from discontinuation of } \\
\text { immunosuppressive treatment to the second } \\
\text { assessment (range) ( } 16 \text { patients) }\end{array}$ & $2(0-9.5)$ months \\
\hline
\end{tabular}

\section{pre-HSCT post-HSCT}

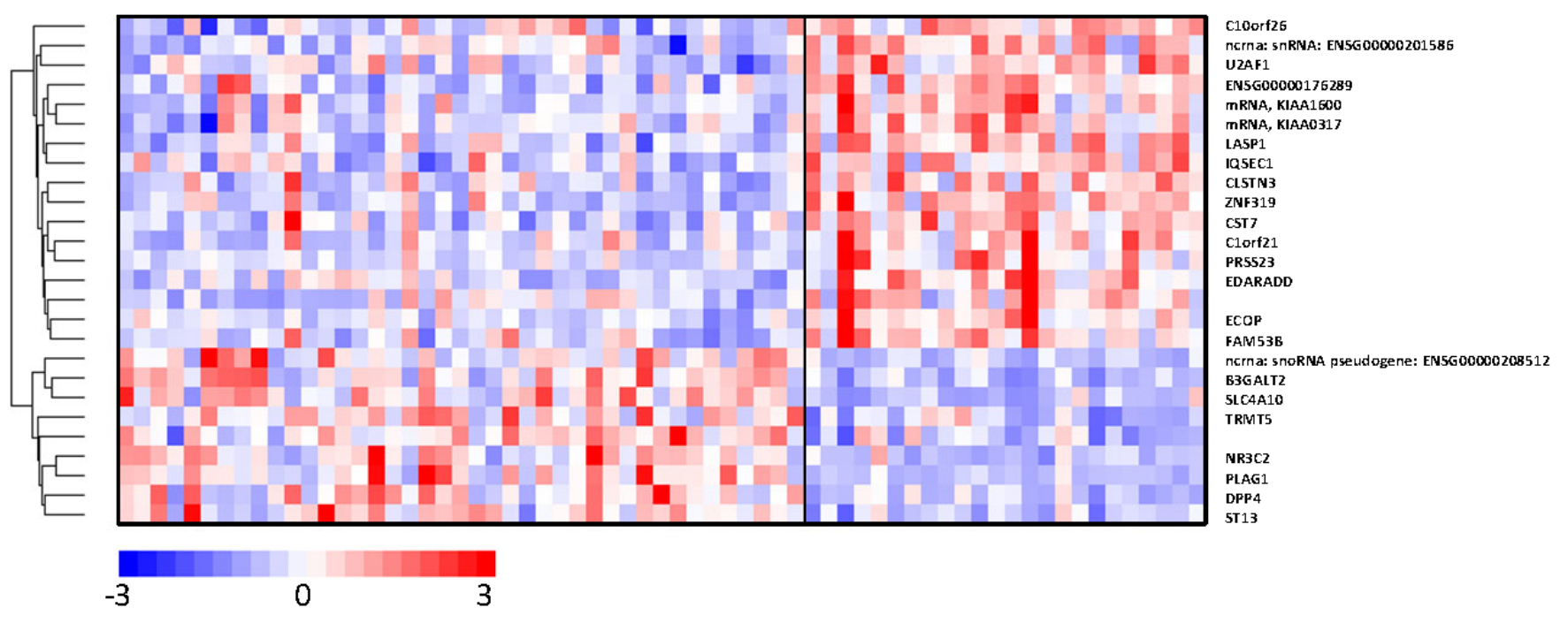

Figure 1. Clustering of signals of the assessed genes 
Table 4. The differentially expressed genes and their function (www.genecards.org/)

\begin{tabular}{|c|c|c|}
\hline Gene & Function of coded protein & Final effect \\
\hline \multicolumn{3}{|c|}{ Activation of function in post-HSCT group } \\
\hline WBP1L & $\begin{array}{l}\text { Expressed in hematopoietic tissues } \\
\text { Proapoptotic } \\
\text { Predispostion to acute leukemia }\end{array}$ & Activation of proliferation and apoptosis \\
\hline U2AF1 & Hematopoiesis regulator & Regulation of hematopoiesis \\
\hline AREL1 & Apoptosis inhibitor & Inhibition of apoptosis \\
\hline Lasp-1 & $\begin{array}{l}\text { Interactions with other proteins, carries signals in cytoplasm and nuclei } \\
\text { Key role in cell structure, physiologic and signaling processes } \\
\text { Overexpression influence cancer progression }\end{array}$ & Activation of proliferation \\
\hline IQSEC1 & Migration & Cells migration \\
\hline CSTN3 & $\begin{array}{l}\text { Modulator of calcium-mediated postsynaptic signals } \\
\text { Modulator of endocrine function } \\
\text { Acceleration of neuronal death } \\
\text { Upregulation in cortical neurons increase vulnerability of neurons }\end{array}$ & $\begin{array}{l}\text { Regulation of signalization } \\
\text { Regulation of endocrine function } \\
\text { Apoptosis activation }\end{array}$ \\
\hline ZFP319 & Implicated in regulating differentiation and cell fate determination & Regulation of differentiation Activation of apoptosis \\
\hline CST7 & $\begin{array}{l}\text { Induction of proliferation } \\
\text { Immune regulation through inhibition of a unique target in the hematopoietic } \\
\text { system } \\
\text { Expression is correlated with metastatic potential of malignant tumors }\end{array}$ & $\begin{array}{l}\text { Activation of proliferation } \\
\text { Regulation of the hematopoietic system }\end{array}$ \\
\hline EDARADD & $\begin{array}{l}\text { Encodes a member of the TNF receptor family } \\
\text { Activation of cell death pathways } \\
\text { Development of ectodermal derivatives }\end{array}$ & $\begin{array}{l}\text { Activation of proliferation } \\
\text { Activation of apoptosis }\end{array}$ \\
\hline ECOP & $\begin{array}{l}\text { Stimulation of proliferation of neoplastic cells Inhibition of apoptosis } \\
\text { Signal transducer activity } \\
\text { Control of the intracellular redox state }\end{array}$ & $\begin{array}{l}\text { Activation of proliferation } \\
\text { Inhibition of apoptosis }\end{array}$ \\
\hline FAM53B & Activation of cells proliferation, maintenance of pluripotent status & Activation of proliferation \\
\hline \multicolumn{3}{|c|}{ Inhibition of function in post-HSCT group } \\
\hline B3GALT2 & Embryogenesis regulator & Inhibition of proliferation \\
\hline SLC4A10 & Regulation of intracellular pH (brain, kidney, small intestine) & Regulation of fluid end electrolyte homeostasis \\
\hline TRMT5 & $\begin{array}{l}\text { Important role in hematopoiesis } \\
\text { Regulation of polypeptide synthesis }\end{array}$ & Inhibition of hematopoiesis \\
\hline $\mathrm{NR} 3 \mathrm{C} 2$ & $\begin{array}{l}\text { Encodes mineralocorticoid receptor } \\
\text { Regulation of aldosterone effects on water and electrolyte homeostasis } \\
\text { Regulation of T-cell migration and redistribution of T-cell subsets to lymph } \\
\text { nodes }\end{array}$ & $\begin{array}{l}\text { Regulation of fluid and electrolyte homeostasis } \\
\text { Inhibition of T-cell migration }\end{array}$ \\
\hline PLAG1 & Regulation of DNA and RNA transcription & Inhibition of proliferation \\
\hline DPP IV & $\begin{array}{l}\text { Activation of T-cell receptor-mediated T-cell activation } \\
\text { Induces T-cell proliferation by binding to chemokines, mitogenic growth } \\
\text { factors , neuropeptides, and peptide hormones } \\
\text { Promotes lymphocyte-epithelial cell adhesion, migration, tube formation } \\
\text { Regulation of expression of hemoglobin genes }\end{array}$ & $\begin{array}{l}\text { Inhibition of T-cells function } \\
\text { Inhibition of proliferation } \\
\text { Inhibition of erythropoiesis }\end{array}$ \\
\hline ST13 & $\begin{array}{l}\text { Suppressor gene } \\
\text { Inhibition of growth and migration of neoplastic cells }\end{array}$ & Activation of proliferation and migration \\
\hline
\end{tabular}


with expected false positive results equal to 2) a total of 24 genes with well-defined function were identified among approximately 33000 genes. Thus, whole genome expression of autologous lymphocytes of 44 children treated with HSCT was compared with genome expression of lymphocytes of 27 allogeneic donors in the recipient's microenvironment. The lymphocytes play basic roles in all immune reactions after HSCT.

Consequently, activation of specific genes in allogeneic lymphocytes genomes is responsible for regulation of engraftment of hematopoietic system, immune reconstitution and immune complication seen after HSCT [13]. In our study gene activation (14 genes) was seen a little more frequently than gene inhibition (10 genes). The balance between proliferation/migration providing to engraftment/reconstitution of cell lines and apoptosis represent the key processes of correction of cells population size $[1,13]$. Consequently, GvHD was the key factor responsible for outcomes of HSCT. The observed inhibition of genes regulating fluid and electrolyte homeostasis is understandable as volume overload and electrolyte disturbances are common complications of HSCT. Erythrocytosis is observed in approximately $36 \%$ of children after several years of follow up (unpublished data). Thus, inhibition of donor genes regulating hematopoiesis and erythropoiesis, which undergo stimulation by recipient's tissues, previously chronically hypoxic due to prolonged anemia, might be a protective mechanism. Four (15\%) patients relapsed after HSCT. As some of the genes stimulating proliferation were described as being overexpressed in various types of cancers(www.genecards.org/), it is possible that they took part in propagation of relapses in our patients.

\section{Conclusion}

In conclusion, the observed activation of genes involved in reconstitution of donor cell lines and those related to immune reactions observed after HSCT seem to form a genetic background of the common processes and immune complications of HSCT. Our data correspond with our previous results indicating pathways of allogenic reactions of donor cells against recipient tissues.

\section{Declaration}

The authors declare no conflict of interest.

\section{Acknowledgment}

This work was supported by national grant number NN 407198737.

\section{Author contributions}

KK, SS designed and performed research, analyzed and interpreted data, and wrote the manuscript. MBM analyzed and interpreted data and helped in drafting the manuscript. AG, MK, MP and KF performed research and collected data. WS, DP analyzed and interpreted data. WB conducted the clinical protocols and interpreted data.

\section{References}

1. Ferrara JL, Levine JE, Reddy P, Holler E (2009) Graft-versus-host disease. Lancet 373: 1550-1561. [Crossref]

2. Engel KL, Mackiewicz M, Hardigan AA, Myers RM, Savic D (2016) Decoding transcriptional enhancers: Evolving from annotation to functional interpretation. Semin Cell Dev Biol S1084-9521: 30140-30149.

3. Pont MJ, Honders MW, Kremer AN, van Kooten C, Out C, et al. (2016) Microarray gene expression analysis to evaluate cell type specific expression of targets relevant for immunotherapy of hematological malignancies. PLoS One 11: e0155165.

4. Inamoto Y, Martin PJ, Flowers ME, Lee SJ, Carpenter PA, et al. (2016) Genetic risk factors for sclerotic graft-versus-host disease. Blood 128: 1516-1524. [Crossref]

5. Lee MT (2004) Power and sample size considerations. In: Analysis of microarray expression Data, 1st ed. Boston: Kluwer academic publishers.

6. Gentleman RC, Carey VJ, Bates DM, Bolstad B, Dettling M, et al. (2004) Bioconductor: open software development for computational biology and bioinformatics. Genome Biol 5: R80.

7. Bengtsson H, Simpson K, Bullard J, Hansen K (2004) Aroma.affymetrix: A generic framework in $\mathrm{R}$ for analyzing small to very large Affymetrix data sets in bounded memory. Tech Rep \#745, Department of statistics, University of California, Berkeley, USA.

8. Irizarry RA, Hobbs B, Collin F, Beazer-Barclay YD, Antonellis KJ, et al. (2003) Exploration, normalization, and summaries of high density oligonucleotide array probe level data. Biostatistics 4: 249-264

9. Smyth GK (2004) Linear models and empirical Bayes methods for assessing differential expression in microarray experiments. Stat Appl Genet Mol Biol 3: 1-25.

10. Smyth GK (2005) Linear Models for microarray data. In: Gentleman R, Carey V, Dudoit S, Irizarry R, Huber W, editors. Bioinformatics and computational biology solutions using R and bioconductor. New York: Springer Verlag.

11. Benjamini Y, Hochberg Y (1995) Controlling the false discovery rate: A practical and powerful approach to multiple testing. J R Stat Soc B Stat Methodol 57: 289-300.

12. Skoczen S, Bik-Multanowski M, Pietrzyk JJ, Grabowska A, Fijorek K, at al. (2016) Genetic background of immune complications after allogeneic hematopoietic stem cell transplantation in children. Stem Cells Int.

13. Flowers ME, Martin PJ (2015) How we treat chronic graft-versus-host disease. Blood 125: 606-615. [Crossref]

14. Socie G, Ritz J (2014) Current issues in chronic graft-versus-host disease. Blood 124 374-384. [Crossref]

15. Nikiforow S, Alyea EP (2014) Maximizing GVL in allogeneic transplantation: Role of donor lymphocyte infusions. Hematology Am Soc Hematol Educ Program 5: 570-575.

16. Strober S (2014) Path to clinical transplantation tolerance and prevention of graftversus-host disease. Immunol Res 58: 240-248. [Crossref]

17. Choi SW, Reddy P (2014) Current and emerging strategies for the prevention of graftversus-host disease. Nat Rev Clin Oncol 11: 536-547. [Crossref]

18. Paczesny S (2013) Discovery and validation of graft-versus-host disease biomarkers. Blood 121: 585-594. [Crossref]

19. Heidegger S, van den Brink MR, Haas T, Poeck H (2014) The role of pattern recognition receptors in graft-versus-host disease and graft-versus-leukemia after allogeneic stem cell transplantation. Front Immunol 18: 1-7.

20. Markey KA, MacDonald KP, Hill GR (2014) The biology of graft-versus host disease: experimental systems instructing clinical practice. Blood 124: 354-362.

21. Reikvam H, Gronningsæter IS, Ahmed AB, Hatfield K, Bruserud o (2015) Metabolic serum profiles for patients receiving allogeneic stem cell transplantation: The pretransplant profile differs for patients with and without posttransplant capillary leak syndrome. Dis Markers.

Copyright: (C2019 Kwiecinska K. This is an open-access article distributed under the terms of the Creative Commons Attribution License, which permits unrestricted use, distribution, and reproduction in any medium, provided the original author and source are credited. 